\title{
Spectrophotometric Method for Determination of Sulfamethoxazole in Pharmaceutical Preparations by Diazotization-Coupling Reaction
}

\author{
*Raghad Sinan and Wasan A. Al-Uzri \\ Chemistry Department, College of Science, Baghdad University, Al-Jadiria, \\ Baghdad-Iraq. \\ "To Whom Correspondence Should be Addressed.
}

\begin{abstract}
A simple, rapid and sensitive spectrophotometric method has been developed for the determination of sulfamethoxazole (SMZ) in pure form and pharmaceutical preparations. The proposed method is based on the diazotization reaction of SMZ with sodium nitrite in hydrochloric acid medium to form diazonium salt, which is coupled with 1-naphthol in sodium hydroxide medium to form azo dye, showing absorption maxima at $525 \mathrm{~nm}$. Linearity was observed from 2-14 $\mu \mathrm{g} \mathrm{mL} \mathrm{m}^{-1} \mathrm{SMZ}$. Statistical analysis of the results and comparison with results by BrattonMarshall's method are also reported.
\end{abstract}

Keywords: Sulfamethoxazole; Spectrophotometric; 1-Naphthol; Diazotization-Coupling Reaction.

\section{Introduction}

Sulfamethoxazole (SMZ), 4-amino-(5methyl-3-isoazolyl) benzensulfonamide, is a white crystalline powder ${ }^{[1]}$. It is short- to medium-acting agents used almost exclusively to treat urinary tract infections. The usual adult dosage is $1 \mathrm{~g}$ of SMZ two or three times daily. The fixed-drug combination of trimethoprimSMZ is the drug of choice for infections such as Pneumocystis jiroveci (formerly $P$ carinii) pneumonia, toxoplasmosis, nocardiosis, and occasionally other bacterial infections ${ }^{[2]}$.

Various methods for SMZ determination have been described, including differential scanning calorimetry ${ }^{[3]}$, spectrofluorimetry ${ }^{[4]}$, potentiometry titration $^{[5]}$, sequential injectionchemiluminescence ${ }^{[6]}$, capillary zone electrophoresis $^{[7]}$, reverse phase-high performance liquid chromatography ${ }^{[8]}$, micellar electrokinetic chromatography ${ }^{[9]}$, spectrophotometry ${ }^{[10]}$ and nuclear magnetic resonance $^{[11]}$.

The Bratton and Marshall's method was considered to be the most commonly used colorimetric method for sulfa drugs. In this method, SMZ was diazotized with dilute hydrochloric acid and sodium nitrite, and the excess of nitrite was destroyed with ammonium sulfamate. A pink color was formed by adding $\mathrm{N}-(1$ naphthyl)ethylenediamine dihydrochloride (NED). The color intensity was measured at $545 \mathrm{~nm}^{[12]}$.
Dizotization and coupling reactions were used for determination of SMZ by diazotization reaction of SMZ and coupling with different coupling agents such as primaquine phosphate ${ }^{[13]}, \mathrm{NED}^{[14]}$, iminodibenzyl $^{[15]}, \quad$ 1-naphthylamine ${ }^{[16]}, \quad 3-$ aminophenol $^{[17]}$ and pyrogallol ${ }^{[18]}$. These reactions required removing of excess of sodium nitrite by sulfamic acid or ammonium sulfamate, or required diluting the azo dye by alcohol, heating step and buffer solution for coupling reaction.

In this work, a rapid and sensitive method using spectrophotometric detection at $525 \mathrm{~nm}$ was proposed for determination of SMZ in pharmaceutical preparations. The method is based on the diazotization reaction of SMZ with sodium nitrite in hydrochloric acid medium; the formed diazonium salt is then coupled with 1-naphthol in sodium hydroxide medium to form a purplish violet watersoluble mono azo dye. This method does not need to get rid of excess sodium nitrite (by addition sulfamic acid or ammonium sulfamate) because of the low concentration of sodium nitrite used by adding equimolar solution of SMZ and sodium nitrite. The proposed method has been successfully applied to the determination of SMZ in pharmaceutical preparations. The method is safe, simple, sensitive, selective and accurate. 


\section{Experimental}

Apparatus

All spectral and absorbance measurements were performed on a Shimadzu UV - VIS 160 (Tokyo, Japan) digital double-beam recording spectrophotometer using $1 \mathrm{~cm}$ quartz cells.

\section{Reagents}

All chemicals were of analytical reagents grade.

1- Sulfamethazole (SMZ) (253.3 $\left.\mathrm{g} \mathrm{mol}^{-1}\right)$ stock standard solution $\left(500 \mu \mathrm{g} \mathrm{mL}^{-1}\right)$ was prepared by dissolving $0.0500 \mathrm{~g}$ of pure SMZ (SDI) in $5 \mathrm{~mL}$ of ethanol and made up to $100 \mathrm{~mL}$ volumetric flask with distilled water. Working standard solutions were prepared by suitable dilution of the stock standard solution.

2- Sodium nitrite $\left(69 \mathrm{~g} \mathrm{~mol}{ }^{-1}\right)$ solution $\left(5 \times 10^{-3} \mathrm{M}\right)$ was prepared by dissolving $0.0690 \mathrm{~g}$ of sodium nitrite (Merck) in distilled water and diluting to the marked in $200 \mathrm{~mL}$ volumetric flask. Then, $3.95 \times 10^{-4} \mathrm{M}$ was prepared by diluting $19.75 \mathrm{~mL}$ of sodium nitrite solution $\left(5 \times 10^{-3} \mathrm{M}\right)$ with distilled water in $250 \mathrm{~mL}$ volumetric flask.

3- Hydrochloric acid solution (1 M) was prepared by diluting $43 \mathrm{~mL}$ of $11.64 \mathrm{M}$ of concentrated hydrochloric acid (BHD) with distilled water in $500 \mathrm{~mL}$ volumetric flask.

4- 1-Naphthol (144.17 g mol $\left.{ }^{1}\right)$ solution $(0.1 \% \mathrm{w} / \mathrm{v})$ was prepared by dissolving $0.1000 \mathrm{~g}$ of 1-naphthol (BHD) in ethanol (BHD) and diluting to the marked with same solvent in $100 \mathrm{~mL}$ volumetric flask. The solution of $3.95 \times 10^{-4} \mathrm{M} 1$-naphthol was prepared by diluting $14.2 \mathrm{~mL}$ of 1-naphthol solution $\left(0.1 \%=6.936 \times 10^{-3} \mathrm{M}\right)$ with distilled water in $250 \mathrm{~mL}$ volumetric flask.

5- 1-Naphthol solution $\left(3.95 \times 10^{4} \mathrm{M}\right)$ was prepared by dissolving $0.01 \mathrm{~g}$ of 1-naphthol (BHD) in ethanol (BHD) and diluting to the marked with same solvent in $100 \mathrm{~mL}$ volumetric flask.

6- Sodium hydroxide solution (4 M) was prepared by dissolving $16.0000 \mathrm{~g}$ of sodium hydroxide (BHD) in distilled water and diluting to the marked in $100 \mathrm{~mL}$ volumetric flask.

\section{Pharmaceutical preparations of sulfamethoxazole}

Pharmaceutical preparations were obtained from commercial sources.

1- Metheprim Tablets (SDI, Samarra-Iraq): $400 \mathrm{mg}$ sulfamethoxazole and $80 \mathrm{mg}$ trimethoprim for each tablet.

2- Supreme Tablets (Micronova-India): $400 \mathrm{mg}$ sulfamethoxazole and $80 \mathrm{mg}$ trimethoprim for each tablet.

3- Co-trimoxazole Suspensions (Pharaonia Pharmaceuticals, Alexandria-Egypt): $200 \mathrm{mg}$ sulfamethoxazole and $40 \mathrm{mg}$ trimethoprim for each $5 \mathrm{~mL}$ of suspension (100 mL).

4- Cotrim Suspensions (Asia Pharmaceutical Industries-Syria):200 mg sulfamethoxazole and $40 \mathrm{mg}$ trimethoprim for each $5 \mathrm{~mL}$ of suspension $(100 \mathrm{~mL})$.

\section{Analytical procedure for calibration}

An aliquot of a standard solution $\left(100 \mu \mathrm{g} \mathrm{mL}^{-1}=3.95 \times 10^{-4} \mathrm{M}\right)$ containing $0.1-3.5 \mathrm{~mL}$ of SMZ was transferred into a series of $25 \mathrm{~mL}$ calibrated flasks. To this solution was added equimolar of sodium nitrite solution $\left(3.95 \times 10^{-4} \mathrm{M}\right)$ and the acidity was adjusted with $3 \mathrm{~mL}$ of $1 \mathrm{M}$ hydrochloric acid solution. The solution was shaken thoroughly. Then, $2 \mathrm{~mL}$ of $0.1 \%$ 1-naphthol and $3 \mathrm{~mL}$ of $4 \mathrm{M}$ sodium hydroxide solutions were added and the contents were diluted to the mark with distilled water and mixed well. After $5 \mathrm{~min}$, the absorbance of the colored azo dye was measured at $525 \mathrm{~nm}$ against the corresponding reagent blank.

\section{Procedure for the assay of pharmaceutical preparations}

1- Tablets solution $\left(500 \mu \mathrm{g} \mathrm{mL}^{-1}\right)$

Weigh and finally powdered of 10 tablets, extract an accurately weighed portion of the powder equivalent to about $50 \mathrm{mg}$ of $\mathrm{SMZ}$ in $5 \mathrm{~mL}$ of ethanol and filtered into a $100 \mathrm{~mL}$ volumetric flask, the residue was washed with distilled water and finally the volume was diluted to the marked with distilled water. Further appropriate solution $\left(100 \mu \mathrm{g} \mathrm{mL}^{-1}\right)$ was made by using distilled water. Three different concentrations of this tablets solution were analyzed in five replicate by analytical spectrophotometric procedure. 
2- Suspension solution $\left(500 \mu \mathrm{g} \mathrm{mL}^{-1}\right)$

An aliquot corresponding to $100 \mathrm{mg}$ of SMZ was dissolved in $5 \mathrm{~mL}$ of ethanol. The solution was filtered into $200 \mathrm{~mL}$ volumetric flask; the residue was washed with $5 \mathrm{~mL}$ of ethanol and finally the volume was diluted to the marked with distilled water.

Further appropriate solutions of pharmaceutical preparations were made by using distilled water.

\section{Results and Discussion}

\section{Preliminary studies}

Throughout the preliminary study on the diazotization reaction of SMZ, with sodium nitrite in hydrochloric acid medium; the formed diazonium salt is then coupled with 1-naphthol in sodium hydroxide medium, a purplish violet water-soluble azo dye was obtained with a maximum absorbance at $525 \mathrm{~nm}$ [Fig. (1)]. The absorbance of the azo dye solution [it produce from mixing $1 \mathrm{~mL}$ of SMZ $\left(100 \mathrm{ppm}=3.95 \times 10^{-4} \mathrm{M}\right), 1 \mathrm{~mL}$ of sodium nitrite $\left(3.95 \times 10^{-4} \mathrm{M}\right), 3 \mathrm{~mL}$ of hydrochloric acid (1 M), $2 \mathrm{~mL}$ of 1-naphthol $(0.1 \%)$, and $3 \mathrm{~mL}$ of sodium hydroxide $(4 \mathrm{M})$ and diluted to $25 \mathrm{~mL}$ with distilled water] measured versus reagent blank [it contain all components above except of SMZ] which has negligible absorbance at this wavelength.

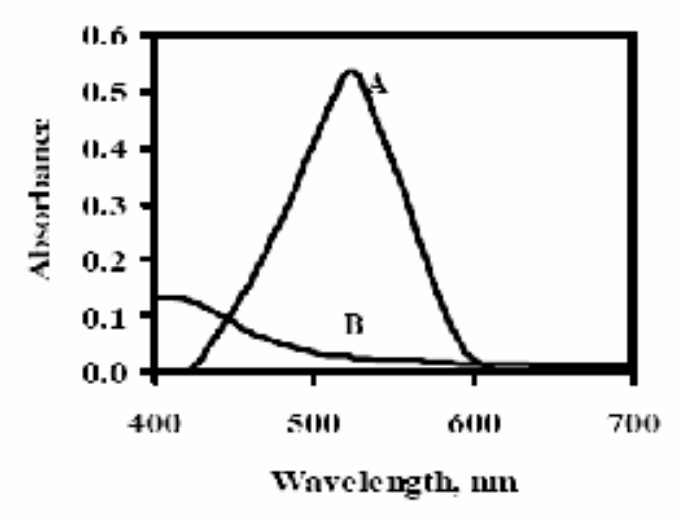

Fig. (1) Absorption spectra of the azo dye against reagent blank $(A)$ and reagent blank against distilled water $(B)$.
Optimization of the experimental conditions

The effects of various parameters on the absorption intensity of the formed product were optimized.

In the subsequent experiments, $1 \mathrm{~mL}$ of SMZ solution $\left(100 \mu \mathrm{g} \mathrm{mL}^{-1}=3.95 \times 10^{-4} \mathrm{M}\right)$ with equimolar of sodium nitrite solution $\left(1 \mathrm{~mL}\right.$ of $\left.3.95 \times 10^{-4} \mathrm{M}\right)$ was taken in $25 \mathrm{~mL}$ final volume and mixing with $3 \mathrm{~mL}$ of acid (1 M), $3 \mathrm{~mL}$ of 1 -naphthol $(0.1 \%)$ and $2 \mathrm{~mL}$ of base $(4 \mathrm{M})$ and diluting to the marked with distilled water. The absorbance of a series of solutions were measured by varying one and fixing the other parameters at $525 \mathrm{~nm}$ versus reagents blanks.

This method does not need to get rid of excess sodium nitrite (by addition of sulfamic acid or ammonium sulfamate) because of the low concentration of sodium nitrite used in equimolar solution of $\mathrm{SMZ}$ and sodium nitrite.

The diazotization reaction of SMZ was formed in acidic medium. Therefore, the effects of different acids solutions (1 M) were studied such as hydrochloric acid, sulfuric acid, phosphoric acid and acetic acid. It was found that hydrochloric acid the most suitable acidic medium for a maximum absorbance and was used in all subsequent experiments.

The coupling reaction of diazotized SMZ with 1-naphthol was formed in alkaline medium. Therefore, the effects of different alkaline solutions ( $4 \mathrm{M}$ ) were studied such as sodium hydroxide, sodium carbonate, potassium hydroxide and ammonium hydroxide. It was found that sodium hydroxide the most suitable alkaline medium for a maximum absorbance and was used in all subsequent experiments.

The effects of different volumes $(0.05-5 \mathrm{~mL})$ of hydrochloric acid $(1 \mathrm{M})$, $(0.05-5 \mathrm{~mL})$ of 1 -naphthol $(0.1 \% \mathrm{w} / \mathrm{v})$ and $(0.5-5 \mathrm{~mL})$ of sodium hydroxide $(4 \mathrm{M})$ were examined on the maximum absorbance of the formed product. Fig. (2) shows that $3 \mathrm{~mL}$ of $\mathrm{HCl}(1 \mathrm{M}), 2 \mathrm{~mL}$ of 1 -naphthol $(0.1 \%)$ and $3 \mathrm{~mL}$ of $\mathrm{NaOH}(3 \mathrm{M})$ were enough to obtain the maximum absorbance.

The effect of temperature on the color intensity of the azo dye [it produce from mixing $1 \mathrm{~mL}$ of $\mathrm{SMZ}(100 \mathrm{ppm}=3.95 \times$ $\left.10^{-4} \mathrm{M}\right), 1 \mathrm{~mL}$ of sodium nitrite $(3.95 \times$ $\left.10^{-4} \mathrm{M}\right), 3 \mathrm{~mL}$ of hydrochloric acid $(1 \mathrm{M})$, 
$2 \mathrm{~mL}$ of 1-naphthol $(0.1 \%)$, and $3 \mathrm{~mL}$ of sodium hydroxide $(4 \mathrm{M})$ and diluted to $25 \mathrm{~mL}$ with distilled water] was studied. In practice, high absorbance was obtained when the color was developed at room temperature $\left(25^{\circ} \mathrm{C}\right)$ that when in ice bath $\left(5^{\circ} \mathrm{C}\right)$ or in water bath $\left(45^{\circ} \mathrm{C}\right)$.
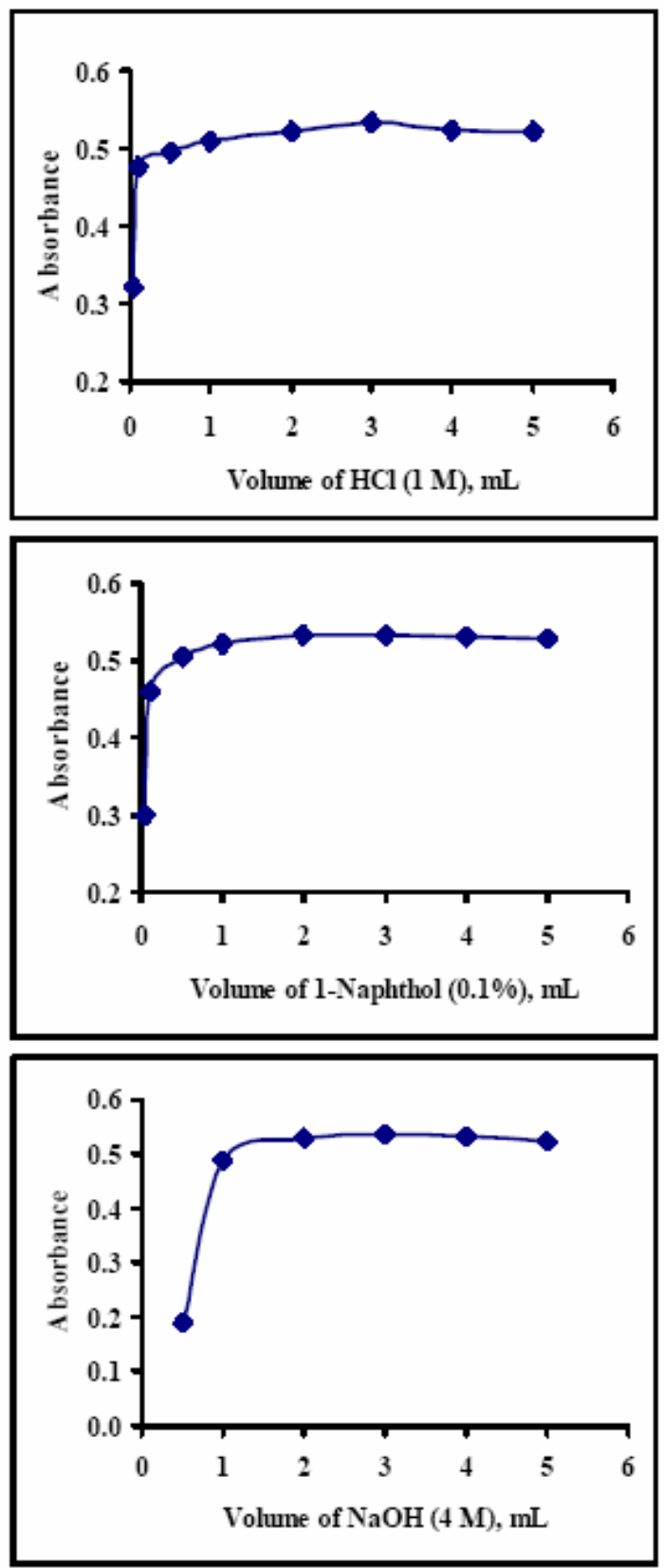

Fig. (2) Optimum conditions for determination of sulfamethoxazole.

The stability of the dye was studied for $2 \mathrm{~h}$ following the mixing of the reagents. The colored azo dye developed rapidly after mixing and attained maximum absorbance about $2 \mathrm{~min}$ at room temperature. The color was stable for a period of $2 \mathrm{~h}$.

The stoichiometry of the product was investigated using the mole ratio and continuous variation methods.

In mole ratio method, increased volumes $(0.5-4 \mathrm{~mL})$ of $3.95 \times 10^{-4} \mathrm{M} 1$-naphthol solution $\left(\mathrm{V}_{\mathrm{R}}\right)$ were added to a $2 \mathrm{~mL}$ of $3.95 \times 10^{-4} \mathrm{M}$ of SMZ $\left(\mathrm{V}_{\mathrm{D}}\right)$ were diazotized using $2 \mathrm{~mL}$ of sodium nitrite $\left(3.95 \times 10^{-4} \mathrm{M}\right)$ and $3 \mathrm{~mL}$ of hydrochloric acid (1 M) and coupled according to analytical procedure in $3 \mathrm{~mL}$ of sodium hydroxide (4 M) and diluted to $25 \mathrm{~mL}$ with distilled water.

In continuous variation method, volumes $(1-6 \mathrm{~mL})$ of $3.95 \times 10^{-4} \mathrm{M}$ portions of SMZ $\left(V_{D}\right)$ were diazotized using equimolar of sodium nitrite $\left(3.95 \times 10^{-4} \mathrm{M}\right)$ and $3 \mathrm{~mL}$ of hydrochloric acid $(1 \mathrm{M})$ and coupled according to analytical procedure with the corresponding complementary volume of $3.95 \times 10^{-4} \mathrm{M}$ 1-naphthol solution $\left(\mathrm{V}_{\mathrm{R}}\right)$ to give a total volume of $6 \mathrm{~mL}$ for $\mathrm{V}_{\mathrm{D}}+\mathrm{V}_{\mathrm{R}}$ in $3 \mathrm{~mL}$ of sodium hydroxide $(4 \mathrm{M})$ and diluted to $25 \mathrm{~mL}$ with distilled water.

The results obtained in Fig. (3) and Fig. (4) show that a 1:1 azo dye was formed between diazotized SMZ (D) and 1-naphthol (R).

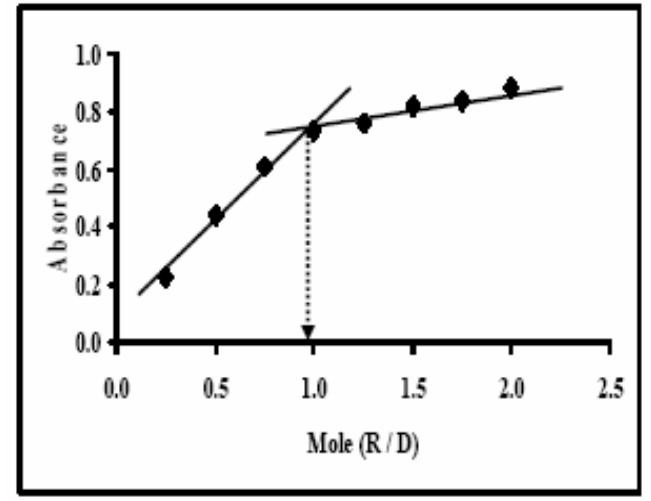

Fig. (3) Mole ratio plot.

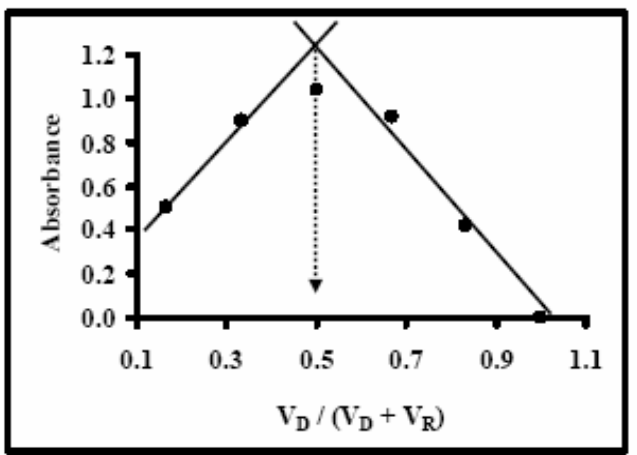

Fig. (4) Continuous variation plot. 
For the diazotization process; it would be expected that $\mathrm{NH}_{2}$ group in $\mathrm{SMZ}$ would be readily diazotized in a hydrochloric acid medium, and that diazonium group would then react with a molecule of 1-naphthol by electrophilic substitution at the 4-position of the coupling agent to produce an intense purplish violet azo dye in sodium hydroxide medium. An investigation of the continuous molar variation of diazotized SMZ and 1-naphthol showed that diazotized SMZ interacts with 1-naphthol in the ratio of $1: 1$. A reaction sequence based on the above results is shown in Scheme (1).

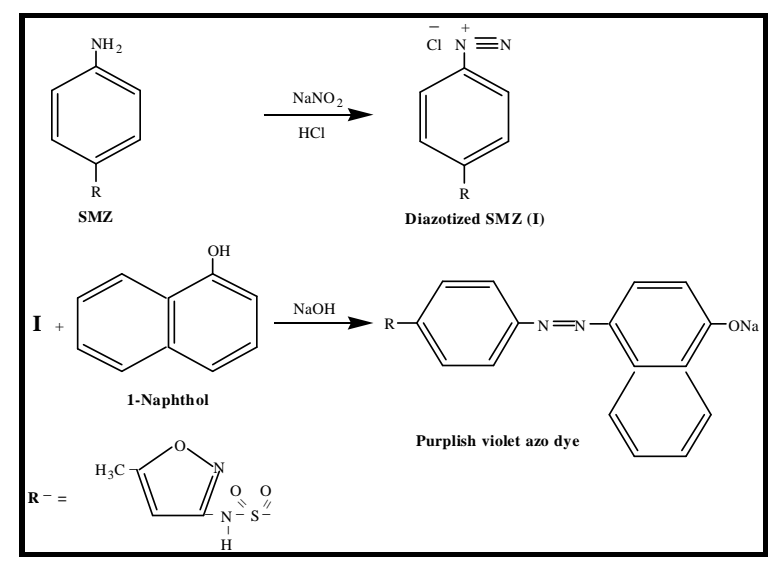

Scheme (1) Reaction sequence.

The product formed was soluble in water. The apparent stability constant was calculated by comparing the absorbance of a solution containing stoichiometric amount of SMZ and 1-naphthol $\left(3.95 \times 10^{-4} \mathrm{M}\right)\left(\mathrm{A}_{\mathrm{S}}\right)$ that of a solution containing a five-fold excess of 1-naphthol reagent $\left(\mathrm{A}_{\mathrm{m}}\right)$ and according to analytical procedure. The stability constant $(\mathrm{K})^{[19]}\left[\mathrm{K}=(1-\alpha) / \alpha^{2} \mathrm{C} ; \alpha=\left(\mathrm{A}_{\mathrm{m}}-\mathrm{A}_{\mathrm{s}}\right) / \mathrm{A}_{\mathrm{m}}\right.$; $\left.\mathrm{A}_{\mathrm{m}}=0.522, \mathrm{~A}_{\mathrm{s}}=0.367 ; \mathrm{C}=1.58 \times 10^{-5} \mathrm{M}\right]$ of the product in water under the described experimental of conditions was $5.059 \times 10^{5} \mathrm{~L} \mathrm{~mol}^{-1}$

In order, assess the possible analytical applications of the proposed method. The effects of some common excipients and compounds frequently found with SMZ in pharmaceutical preparations, such as magnesium stearate, lactose, talc, starch, poly vinyl pirrolidone (PVP) and trimethoprim (TMP) were studied by analyzing. Synthetic sample solutions containing $4 \mu \mathrm{g} \mathrm{mL}^{-1}$ of SMZ and excess amounts (10-fold excess) of each excipient, none of these substances interfered seriously [Table (1)].

Table (1)

Determination of $4 \mu \mathrm{g} \mathrm{mL}^{-1}$ of

SMZ in the presence of excipients.

\begin{tabular}{|c|c|c|c|c|}
\hline \multirow[t]{2}{*}{$\begin{array}{l}\text { Excipient, } \\
40 \mu g \mathrm{~mL}^{-1}\end{array}$} & $\begin{array}{c}\text { Concn. } \\
\text { of } S M Z \text {, } \\
\mu g m L^{-1}\end{array}$ & \multirow[t]{2}{*}{$E_{r e b} \%$} & \multirow[t]{2}{*}{$\begin{array}{c}\text { Rec., } \\
\%\end{array}$} & \multirow[t]{2}{*}{$\begin{array}{c}\text { RSD } \\
\%\end{array}$} \\
\hline & Found* & & & \\
\hline Mg-stearate & 4.002 & +0.550 & 100.550 & 1.143 \\
\hline Lactose & 4.030 & +0.750 & 100.750 & 1.355 \\
\hline Talc & 4.003 & +0.075 & 100.075 & 0.740 \\
\hline Starch & 3.913 & -2.175 & 97.825 & 1.794 \\
\hline PVP & 3.986 & -0.350 & 99.650 & 0.971 \\
\hline TMP & 4.007 & +0.175 & 100.175 & 0.575 \\
\hline
\end{tabular}

*Average of five determination, $\boldsymbol{E}_{\text {rel }}=$ relative error, Rec. $=$ recovery, $R S D=$ relative standard deviation.

\section{Analytical characteristics of spectrophotometric method}

For proposed method, the calibration graph was obtained by the procedure described previous and a series of standard solutions was analyzed in triplicate to test the linearity. The molar absorptivity $(\varepsilon)$, the Sandell's sensitivity $(\mathrm{S})$, the slope (a), the intercept (b), the correction coefficient (r) and correlation of determination $\left(\mathrm{r}^{2}\right)$ were evaluated by a least squares regression analysis and are included in Table (2).

Statistical evaluation ${ }^{[20]}$ of the regression line gave the values of standard deviations for residuals $\left(S_{\mathrm{y} / \mathrm{x}}\right)$, slope $\left(\mathrm{S}_{\mathrm{a}}\right)$ and intercept $\left(\mathrm{S}_{\mathrm{b}}\right)$ at 95\% confidence are shown in the same Table. These small figures point out to the high precision of the proposed method. The limit of detection (LOD) and limit of quantitative (LOQ) were determined using the formula: LOD or LOQ $=\mathrm{k} \mathrm{S}_{\mathrm{y} / \mathrm{x}} / \mathrm{b}$, where $\mathrm{k}=3$ for LOD and 10 for LOQ. The LOD and LOQ values are shown in Table (2). 
Table (2)

Data for calibration graph for SMZ using the proposed method.

\begin{tabular}{|c||c|}
\hline Parameter & Value \\
\hline \hline Linearity range, $\mu \mathrm{g} \mathrm{mL}^{-1}$ & 2 - 14 \\
\hline \hline $\mathrm{r}$ & 0.9998 \\
\hline $\mathrm{r}^{2}$ & 0.9996 \\
\hline \hline$\varepsilon, \mathrm{L} \mathrm{mol}^{-1} \mathrm{~cm}^{-1}$ & $3.3714 \times 10^{4}$ \\
\hline $\mathrm{S}, \mu \mathrm{g} \mathrm{cm}^{-2}$ & $7.5132 \times 10^{-3}$ \\
\hline \hline $\mathrm{a}, \mathrm{mL} \mathrm{mg}^{-1}$ & 0.1331 \\
\hline \hline $\mathrm{b}$ & -0.0034 \\
\hline \hline $\mathrm{S}_{\mathrm{y} / \mathrm{x}}$ & $1.0403 \times 10^{-2}$ \\
\hline $\mathrm{S}_{\mathrm{a}}$ & $7.2721 \times 10^{-4}$ \\
\hline $\mathrm{S}_{\mathrm{b}}$ & $5.4876 \times 10^{-3}$ \\
\hline \hline $\mathrm{LOD}, \mu \mathrm{g} \mathrm{mL}$ & 0.2345 \\
\hline \hline $\mathrm{LOQ}, \mu \mathrm{g} \mathrm{mL}$ & 0.7816 \\
\hline \hline
\end{tabular}

Accuracy and precision of the proposed spectrophotometric method

The accuracy and precision of the proposed method were tested by analyzing five replicate of SMZ by proposed spectrophotometric method for three different concentrations of SMZ. The low values of $\mathrm{E}_{\text {rel }} \%$ summarized in Table (3). The RSD\% was found to be less. These values indicated the high accuracy and precision of the proposed method.
Table (3)

Accuracy and precision of the proposed method.

\begin{tabular}{|c|c|c|c|c|}
\hline \multicolumn{2}{|c|}{$\begin{array}{c}\text { Concn. of SMZ, } \\
\mu \mathrm{g} m L^{-1}\end{array}$} & \multirow[t]{2}{*}{$E_{\text {reb }} \%$} & \multirow[t]{2}{*}{$\begin{array}{c}\text { Rec., } \\
\%\end{array}$} & \multirow[t]{2}{*}{$\underset{\%}{R S D}$} \\
\hline Present & Found* & & & \\
\hline 4.000 & 3.975 & -0.625 & 99.375 & 1.524 \\
\hline 8.000 & 7.981 & -0.238 & 99.762 & 0.360 \\
\hline 12.000 & 11.759 & -2.008 & 97.992 & 0.325 \\
\hline
\end{tabular}

*Average of five determination.

\section{Pharmaceutical Applications}

The proposed method was applied successfully to analysis of different pharmaceutical preparations containing SMZ and the results are summarized in Table (4). For all preparations examined, the assay results of proposed method were in good agreement with the declared content.

The results obtained by the proposed method were compared with BrattonMarshall's method ${ }^{[12]}$ [Table (5)] by applying the F-test and t-test at 95\% confidence level. The calculated values for F (5.527) and $\mathrm{t}$ (0.069) for proposed method did not exceed the critical values of $F_{4,4}=9.605$ and $t=2.306$ $\left(n_{1}+n_{2}-2=8\right)$. These confirming that there are no significant differences between the proposed method with Bratton-Marshall's method with respect to precision and accuracy in the determination of SMZ in pharmaceutical preparations.

Table (4)

Application of the proposed method for determination of SMZ in pharmaceutical preparations.

\begin{tabular}{|c|c|c|c|c|c|}
\hline \multirow{2}{*}{ Pharmaceutical preparation } & \multicolumn{2}{|c|}{ Concn. of SMZ, $\mu \mathrm{g} \mathrm{mL}^{-1}$} & \multirow{2}{*}{$\begin{array}{c}E_{\text {rel }}, \\
\%\end{array}$} & \multirow{2}{*}{$\begin{array}{c}\text { Rec., } \\
\%\end{array}$} & \multirow{2}{*}{$R S D, \%$} \\
\hline & Present & Found" & & & \\
\hline \multirow{3}{*}{$\begin{array}{c}\text { Metheprim } \\
\text { Tablets }\end{array}$} & 4.000 & 3.918 & -2.050 & 97.950 & 2.180 \\
\hline & 8.000 & 7.921 & -0.988 & 99.012 & 1.407 \\
\hline & 12.000 & 11.997 & -0.025 & 99.975 & 0.886 \\
\hline \multirow{3}{*}{$\begin{array}{l}\text { Supreme } \\
\text { Tablets }\end{array}$} & 4.000 & 3.985 & -0.375 & 99.625 & 1.835 \\
\hline & 8.000 & 8.005 & +0.063 & 100.063 & 0.457 \\
\hline & 12.000 & 11.991 & -0.075 & 99.925 & 0.262 \\
\hline \multirow{3}{*}{ Co-trimoxazole Suspensions } & 4.000 & 4.005 & +0.125 & 100.125 & 1.970 \\
\hline & 8.000 & 8.014 & +0.175 & 100.175 & 0.432 \\
\hline & 12.000 & 12.088 & +0.733 & 100.733 & 2.414 \\
\hline \multirow{3}{*}{$\begin{array}{c}\text { Cotrim } \\
\text { Suspensions }\end{array}$} & 4.000 & 4.032 & +0.800 & 100.800 & 1.741 \\
\hline & 8.000 & 8.026 & +0.325 & 100.325 & 0.627 \\
\hline & 12.000 & 12.000 & 0.000 & 100.000 & 0.365 \\
\hline
\end{tabular}

* Average of five determinations. 
Table (5)

Comparison of the proposed method with Bratton-Marshall's method for determination of pharmaceutical preparations of SMZ.

\begin{tabular}{|c||c|c||}
\hline \multicolumn{1}{|c||}{ Pharmaceutical preparation } & \multicolumn{2}{c|}{ Recovery*, \% } \\
\cline { 2 - 3 } & $\begin{array}{c}\text { Proposed } \\
\text { method }\end{array}$ & Bratton-Marshall's method \\
\hline \hline Pure SMZ & 100.000 & 100.000 \\
\hline \hline Metheprim Tablets & 98.979 & 99.700 \\
\hline \hline Supreme Tablets & 99.871 & 99.925 \\
\hline Co-trimoxazole Suspensions & 100.344 & 100.225 \\
\hline CotrimSuspensions & 100.375 & 99.625 \\
\hline
\end{tabular}

* Average of five determination.

\section{Conclusions}

The proposed method offers clear advantages for the fast determination of SMZ in the presence of the related compounds, such as TMP in pharmaceutical preparations. The method was found to be very simple, rapid, low cost, and fairly selective than some of the reported colorimetric methods. They had an advantage of being accurate, did not require the removal of excipients, any chemical sample pretreatment, temperature control, $\mathrm{pH}$ control, solvent extraction step, and expensive reagents and solvents.

The proposed method was applied to the analysis of SMZ in tablets and suspensions solutions, suggesting that they used as a reliable and advantageous alternative to the other previously exported methods for routine analysis of SMZ in these samples.

\section{References}

[1] "British Pharmacopoeia on CD-ROM",, The Stationery Office Ltd., London. 3rd ed, 2001.

[2] B.G. Katzung, "Basic and Clinical Pharmacology", The McGraw-Hill Companies, Inc., USA, 10th ed., 2007, pp. 1061.

[3] Y.M. Issa, A.L. El-Ansary and W. Selim, "Enthalpimetric determination of sulfa drugs in pure form and pharmaceutical formulations", Anal. Lett., Vol. 31, No. 1, 1998, pp. 131-146.

[4] C.C. Blanco, A.S. Carretero, S.F. Peinado, M.R. Ceba and A.F. Gutierrez, "Determination of the antibacterial drug sulfamethoxazole in pharmaceutical preparations containing trimethoprim by spectrofluorimetry after derivatization with fluorescamine", Fresenius J. Anal. Chem., Vol. 365, No. 5, 1999, pp. 444-447.

[5] N.M.A.K. Nazer, T.K. Shabeer and P. Riyazuddin, "Indirect potentiometric titration of sulphamethoxazole in the presence of trimethoprim in co-trimazole tablets using copper based mercury film electrode", Chem. Pharm. Bull., Vol. 49, No. 3, 2001, pp. 278-281.

[6] H. Paseková, M. Polášek, J.F. Cigarro and J. Dolejšová, "Determination of some sulphonamides by sequential injection analysis with chemiluminescence detection", Anal. Chim. Acta, Vol. 438, No. 1-2, 2001, pp. 165-173.

[7] J.J.B. Nevado, G.C. Penalvo and F.J.G. Bernardo, "Determination of sulfamethoxazole, sulfadiazine and associated compounds in pharmaceutical preparations by capillary zone electrophoresis", J. Chromatogr. A, Vol. 918, No. 1, 2001, pp. 205-210.

[8] C. Akay and S.A. Ozkan, "Simultaneous LC determination of trimethoprim and sulphamethoxazole in pharmaceutical formulations", J. Pharm. Biomed. Anal., Vol. 30, No. 4, 2002, pp. 1207-1213.

[9] J.M.L. Gallego and J.P. Arroyo, "Determination of prednisolone and the most important associated compounds in ocular and cutaneous pharmaceutical preparations by micellar electrokinetic 
capillary chromatography", J. Chromatogr. B, Vol. 784, No. 1, 2003, pp. 39-47.

[10] A.S. Al-Attas, "Charge transfer complex formation in spectrophotometric and conductometric determination of some sulfonamides", Saudi Pharm. J., Vol. 11, No. 3, 2003, pp. 141-145.

[11] A.A. Salema, H.A. Mossab and B.N. Barsoumb, "Application of nuclear magnetic resonance spectroscopy for quantitative analysis of miconazole, metronidazole and sulfamethoxazole in pharmaceutical and urine samples", J. Pharm. Biomed. Anal., Vol. 41, No. 2, 2006, pp. 654-661.

[12] A.C. Bratton and E.K. Marshall, "A new coupling component for sulfanilamide determination", J. Biol. Chem., Vol. 128, 1939, pp. 537-550.

[13] M.E.S. Metwally, "Primaquine phosphate as a promising substitute for $\mathrm{N}$-(1-naphthyl) ethylenediamine; II. Analysis of sulfa drugs in pharmaceutical dosage forms and biological samples", Anal. Sci., Vol. 15, No. 10, 1999, pp. 979-984.

[14] N.M.A. Al-Hamadany, "Spectrophotometric determination of some sulfa drugs (sulfameter, sulfamethizole and sulfamethoxazole)", M. Sc. Thesis, Mosul University, 2002, pp. 55-77.

[15] P. Nagaraja, R. Sunitha, R.A. Vasantha and H.S. Yathirajan, "Iminodibenzyl as a novel coupling agent for the spectrophotometric determination of sulfonamide derivatives", Euorpean J. Pharm. and Biopharm., Vol. 53, No. 2, 2002, pp. 187-192.

[16] J. Fan, Y. Chen, S. Feng, C. Ye and J. Wang, "Flow-injection spectrophotometric determination of sulfadiazine and sulfamethoxazole in pharmaceuticals and urine", Anal. Sci., Vol. 19, No. 3, 2003, pp. 419-422.

[17] P. Nagaraja, H.S. Yathirajan, C.R. Raju, R.A. Vasantha, P. Nagendra and M.S.H. Kumar, "3-Aminophenol as a novel coupling agent for the spectrophotometric determination of sulfonamide derivatives", Il Framaco, Vol. 58, No. 12, 2003, pp. $1295-1300$.

[18] N.S. Othman, "Spectrophotometric determination of some sulfonamides in aqueos solution via azo-dye formation reaction”, J. Educ. and Sci., Vol. 17, 2005, pp. 32-39.

[19] M. Q. Al-Abachi and T. S. Al-Ghabsha, "Fundamentals of Analytical Chemistry", Press of Mosul University, Mousl, 1983, pp. 346.

[20] J.N. Miller and J.C. Miller, "Statistic and Chemometrics for Analytical Chemistry", Pearson Education Limited, London, 4th ed., 2000.

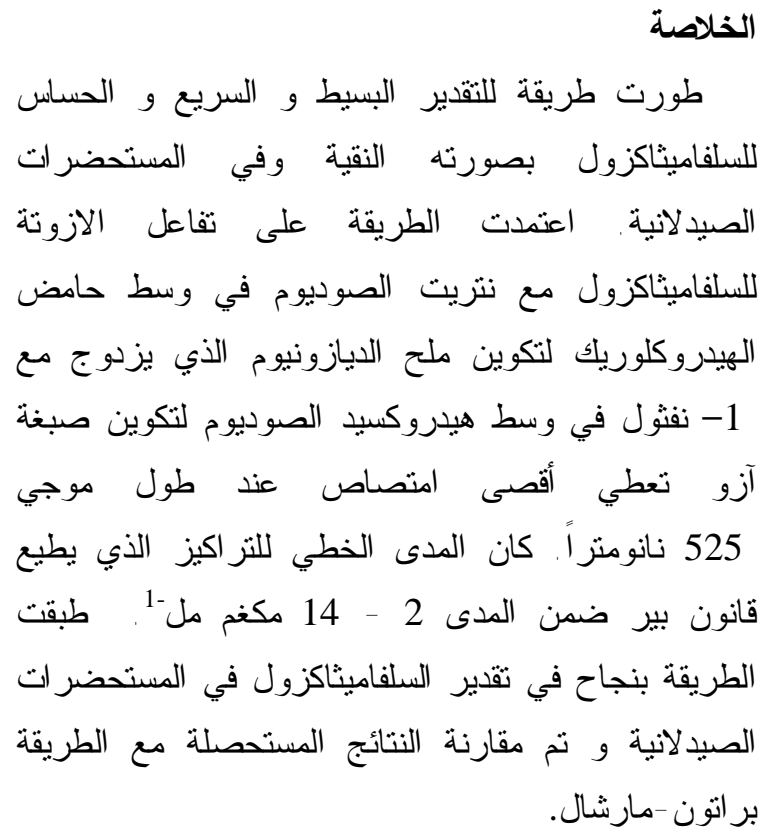

